\title{
Japanese and Korean/Chinese Reconciliation through Experience-based Cultural Interaction
}

\author{
David Palmer
}

\begin{abstract}
Reconciliation between the Japanese people and those of China and Korea may have better prospects for advancement through a new cultural approach that is experience-based, starting at individuals' levels and interests, rather than focusing solely on victimization and confining activism to more conventional organizationbuilding and public protests. The peace movement opposed to nuclear weapons has continued to center around the atomic bombings of Hiroshima and Nagasaki, but in the past has not fully dealt with Korean and Chinese forced labor by Imperial Japan. However, the alternative experience-based cultural approach by a number of individuals and relatively small organizations has combined these two historical issues. This article highlights examples of two Japanese who directly witnessed Chinese and Korean forced labor in wartime Japan, but who also opposed the atomic bombings. They became activists themselves in the postwar era and utilized traditional cultural forms (tanka poetry and sumi drawing) to help create awareness of the full dimension of Japan's wartime history. There is strong potential for extending this alternative social movement model, which may be more effective in achieving reconciliation of unresolved historical injustices, to younger generations.
\end{abstract}

Keywords Japan, World War II, Korea, China, hibakusha, forced labor

\section{Introduction}

In September 2008, a series of extraordinary sumi ink drawings of Chinese prisoners of war (POWs) used as forced laborers in Japan was exhibited at a Kobe community center. The artist, Shimura Bokunenjin (志村墨然人), depicted the brutal experience of these Chinese in Hokkaido and Aomori Prefecture coal mines in the last year of World War II. The drawings were large in scale. The detail in the faces, bodies, surroundings, and sense of violence combined historical realism with artistic mastery. Bokunenjin painted these scenes from memory based on his own experiences. He had been a dormitory supervisor at 
the coal mine of Kajima-gumi (a zaibatsu that became Kajima Corporation after the war) in Hokkaido, which was overseen by the Japanese Imperial Army and its military police division, the Kempeitai. He only began painting this subject in his sumi painting when he had reached his eighties. In the decades after World War II, he pursued his artistic craft by drawing traditional subjects-flowers, insects, birds, trees, and landscapes-subjects completely free of any recollection of Japan's wartime authoritarianism and brutality.

His decision to record what he had witnessed in 1945 by drawing that history, some 60 years later, coincided with an upsurge in the movement to seek justice for Korean and Chinese workers who had been used as forced labor under Japan's imperial fascism. Bokunenjin's artistry, however, has differed from prevailing patterns of protest related to unresolved issues of the Pacific War because of its grounding in deep personal experiences of a history that, too often, has been concealed. His work represents an alternative basis for a social movement for World War II reconciliation between Japan and its neighbors. In contrast to mobilizing large numbers of people for demonstrations, this alternative approach incorporates grassroots cultural-political interaction, starting at the individual level before moving to another level of activism. Also in contrast to the numerous peace and reconciliation movements in Japan and elsewhere, Bokunenjin's artistic work exposes Japan's wartime political economy, with the responsibility for its crimes that involve not only the military and wartime government, but also the role of the zaibatsu, Japan's predecessors to its present-day multinational corporations.

\section{The Pacific War and Social Movements in Japan}

In Japan, the longest sustained social movements relating to the issue of war have been those against nuclear weapons. They have been concentrated in Hiroshima and Nagasaki, but have also had considerable participation nationally. The origins of this movement reflected overwhelming public opposition to nuclear weapons in Japan's immediate postwar period (Wittner 1993, 39-54). Gensuikyo (Japan Council Against Atomic and Hydrogen Bombs), the largest Japanese organization opposed to nuclear weapons in the 1960s, led coalitions that mobilized hundreds of thousands in protests during that decade. However, it declined rapidly in later decades due to many factors, including internal factionalism and leftwing political disputes with Gensuikin (Japan Congress Against Atomic and Hydrogen Bombs), its rival anti-nuclear organization; the rise of other pressing social protest issues; and the cooptation of the legacy of the Hiroshima atomic bombing by mainstream political forces (Wittner 1997, 41-3, 141-46, 242-62; Oe 1981). The movements against U.S. bases in Japan-including huge mobilizations in Okinawa, the student-centered protests against the renewal of the Japanese-U.S. 
Security Treaty (AMPO) in 1960, and the antiwar protests against the Vietnam War-were greater in size at times than those against nuclear weapons; but the anti-nuclear weapons movement maintained a longer, more sustained following, even if its energy and influence subsided substantially (Kurita 2010; SasakiUemura 2001). By the 1990s, much of the movement against nuclear weapons in Japan had become institutionalized, with annual commemorations in Hiroshima and Nagasaki official statements by each city's mayor (the "peace declarations"), as well as the presence of mainstream politicians, academics, and others who would not associate with more radical grassroots movements.

Both cities established peace museums, with millions of visitors passing through them, as well as research centers and archives. Hiroshima became a major tourist destination for Japanese visitors, but also for international travelers. Some observed that Hiroshima even seemed to have become a "brand" that was sold to the world-its identity linked to the image of the atomic bomb dome, the peace park, and the symbolic paper "peace cranes." Japanese Prime Ministers, but also liberal progressives from overseas, routinely made August visits for the massive Hiroshima commemoration. Only in 1970 was a memorial erected in memory of the thousands of Koreans who died in the atomic bombing, but it was placed outside the Hiroshima Peace Memorial Park and was the subject of major controversy (Yoneyama 1999, 151-86). Only in the last decade was it finally relocated inside official Memorial Park boundaries. The use of thousands of Korean forced laborers in Hiroshima and Nagasaki, including the Mitsubishi Shipyards, remains a part of the atomic bomb history still marginalized in the atomic bomb museums, even if this has improved from previous exclusion of this history in the exhibitions.

The movement against nuclear weapons, whether community-based or institutionalized into the mainstream-even commercialized to a degree-has consistently called for global nuclear weapons disarmament. In this sense, both the community-based and institutionalized sides of the movement have played a positive role in their advocacy of peace. Both have advocated remembering the actual history of what the atomic bombs did to the Japanese people in these cities and the total destruction of these cities. However, there has been a tendency in the institutionalized side of this movement to view Japan as the only victim of the atomic bombs, and a parallel tendency to downplay the role of Japan as invader of Asia that carried out war crimes (Orr 2001; Yoneyama 1999).

Over the last two decades, numerous scholars and popular writers have covered the controversy of Japanese as "victims" of the atomic bombs versus Japanese as "guilty" of war crimes (Buruma 1994; Dower 2012; Hogan 1996; Orr 2001, 36-70). This writing has tended to focus on memorials, postwar debates in Japanese publications, and divisions in Japanese popular opinion and politics on wartime "memory." However, there has been a distinct absence of writing on the connection of economic institutions-the zaibatsu acting in concert with the 
militarized wartime government-to this memory, and the connection of Korean and Chinese forced labor to these zaibatsu. There are scholars who are exceptions, but their work needs to be taken far more seriously, as it focuses on institutional practices and ongoing litigation related to historical realities, drawn on hard evidence rather than memorials and memory controversies (Underwood 2006; Underwood 2010). The analysis here is on the use of non-memorial cultural forms to assist in recalling specific history of events, people, and places that have been officially suppressed by both government and business institutions, rather than to discuss the issues of memorialization of that history.

Although the anti-nuclear movement in Japan has been eclipsed by other social movements for change in recent decades (Funabashi 2010; Fukuoka and Tsujiyama 2010), in the last two years the Fukushima meltdown catastrophe has renewed protests against nuclear power, with broad public support that promises to have some impact on revitalizing the movement against nuclear weapons. However, an alternative approach that goes beyond just demonstrations, beyond standard organization-building, and also beyond the nuclear issue itself may hold the key to future social movements that can engage a larger constituency and can succeed in achieving a more sustained involvement of supporters.

\section{Bokunenjin's Sumi Drawings of Chinese Forced Laborers ${ }^{1}$}

Bokunenjin's artistic works represent a radical break from this "victim" orientation towards a more internationalist outlook that holds real promise for reconciliation between Japan and those countries it invaded and occupied in the past-especially Korea and China. Bokunenjin's works take us outside the nationalist orientation exhibited by all sides. He focuses on the history that he saw first-hand, from the oppressor's side, and takes us into the complexity of those who were inside Japan's horrendous war economy on the home islands, even as he ruthlessly conveys a self-criticism for his connection to that war economydespite his efforts to assist the Chinese imprisoned under his supervision.

Bokunenjin's sumi drawings form part of a longer tradition, both in Japan and internationally, of artists drawing, etching, and painting scenes of war and its victims as a way to protest the inhumanity of war. From Goya to Picasso, this form of expression has galvanized Western anti-war sentiment for two centuries. The Hiroshima atomic bomb murals of Maruki Iri and Maruki Toshi are the most well known examples of this artistic practice in modern Japan (Dower and Junkerman 1986; Minear 1990, 371-78). Movements, from the 1960s to the present, have continued this tradition among artists throughout the world.

Bokunenjin, however, paints from the vantage point of one who was in the ranks of the oppressor, in his case Japanese military and zaibatsu supervision of Chinese forced laborers. He depicts the full horror of the ordeal of the Chinese, 
but he also fully portrays their spirited yet failed resistance to their oppressors. He identifies with the laborers rather than their oppressors, perhaps because he felt trapped in the system of the oppressors-a system that he disliked intensely but could not openly resist. Implicitly, he offers us an alternative model that reveals the possibilities of grassroots, cultural-political interaction that starts at the individual's level of experience, but does not allow us to fall back on the "victim" versus "oppressor" paradigm. His victims-Chinese POWs who were used as slave laborers-resisted through outright rebellion, but they also maintained a degree of dignity through their own values and culture inside Kajima-gumi's slave camp. Their physical-but also cultural-resistance has remarkable historical parallels with the history of African-American slavery, and then Southern segregation and terror after emancipation that some historians have called "slavery by another name" (Berlin 2010; Blackman 2008). The oppressor was not simply the company guards and the military, but also included local Japanese villagers.

Bokunenjin's work is part of a recent trend of historical recognition most prominent among those engaged in researching and uncovering the history of Chinese forced labor. The catalogue for his exhibition includes a statement by Tanaka Hiroshi of the Chugokujin Kyoseirenko o Kangaerukai (Association for the Acknowledgement of Chinese Forced Labor) (Shimura 2008a), which is only one of a number of such organizations in Japan. His exhibition received favorable coverage in Chugoku Shimbun, and it further substantiates evidence published by Japanese researchers on Chinese forced labor during World War II. The catalogue includes a detailed map of Japan with Chinese forced labor worksites at numerous companies, as well as statistics on the number of Chinese forced laborers in each company and location. Even though his work is not directly linked to a specific organization, it does represent an artistic and political movement of an alternative type based on personal experience that is a crucial source of historical memory. His artistic documentation was the first historical recognition of Kajima-gumi's Chinese forced labor system at the Shiribeshi, Hokkaido coal mine. The analysis presented here does not aim to prove Bokunenjin's connection to, or influence on, the movements on behalf of former forced laborers, but instead seeks to view his artistic work as a basis for the cultural grounding of present and future social movements of a different type.

In his introduction to the exhibit's catalogue, Bokunenjin explains why he waited more than 60 years to depict the scenes from his Hokkaido experiences during the last year of the war.

For a long time I continued to remain silent about this difficult and turbulent experience. After 50 years, I walked over the same ground where all of this had occurred. However, I could not forget the circumstances of the Chinese who had inscribed themselves into this land where the original village had been (Shimura 2008a). 
He discovered that there was no trace of the original worksite and village constructed in 1945 by Kajima-gumi company, and developed as a major coal mining project in conjunction with the Tanigawa Coal Mining Company. The complex, built in a remote part of northwest Hokkaido on the Shakotan Peninsula in Shiribeshi subprefecture, was called the Empire Coal Mining Development. It included the mine, a new village, and a slag treatment area. The company employed him as a supervisor of the Taizan Dormitory that housed the Chinese. Previously he had worked in Kajima-gumi's personnel office in another location, but the company compelled him to directly supervise forced laborers in the dormitory at the remote mine site. The Kempeitai oversaw the POWs, with Bokunenjin working under a commander of its labor division. The operation typified Japan's wartime militarized economy, which in this location was operated by Kajima-gumi as a private company, but its labor was regulated and disciplined by a military arm of the imperial state.

Bokunenjin ascribed the absence of any physical evidence of the forced labor worksite and dormitories two decades later partly to the severe snow storms of Hokkaido that had gradually rotted away the structures. When he walked through the area he had known so well in 1945, he found it overgrown with plants and trees. Another factor, however, contributed to the physical erasure of this history. In 1968, the development of a nuclear power plant began on the site. Digging for a coolant pond as part of the nuclear facility was underway and had displaced much of the original traces of the paths where hundreds of Chinese had carried coal from the mine to rail cars. They had ferried the coal in large baskets hanging from slings carried by two men each. Bokunenjin decided to consult local histories of the location, which now had a small town with the name Kyowacho. Both the newer published history of Kyowacho and an earlier history of the original village failed to mention the Chinese forced laborers. Even a friend of Bokunenjin who accompanied him on his walking survey had no idea that Chinese forced laborers once worked at the mine. Bokunenjin concluded that this complete absence of evidence could not be a coincidence. The new nuclear plant construction would have turned up incriminating evidence, and he believed that this apparently had to be suppressed to avoid a scandal.

Bokunenjin's drawings portray a range of scenes and events (see Figure 1-Figure 6). ${ }^{2}$ The early history of the mine, which began operation decades before the Pacific War, utilized convict labor. He conveys this in a wide panorama scene at the mine's edge. It was an open pit mine that used convicts, including tattooed yakuza, with picks and shovels being directed by a supervisor wearing a jacket with Kajima-gumi's "Ka" katakana on it. The supervisor crudely points at workers and carries a long iron stick to discipline any misbehavior. Kempeitai and a Japanese Imperial Army soldier symbolically look on from the corner, one of them casually holding his sword in one hand and a cigarette in the other. There would not have been military presence of this type at the mine until World War 
Figure 1. Kajima Boss and Work Gang

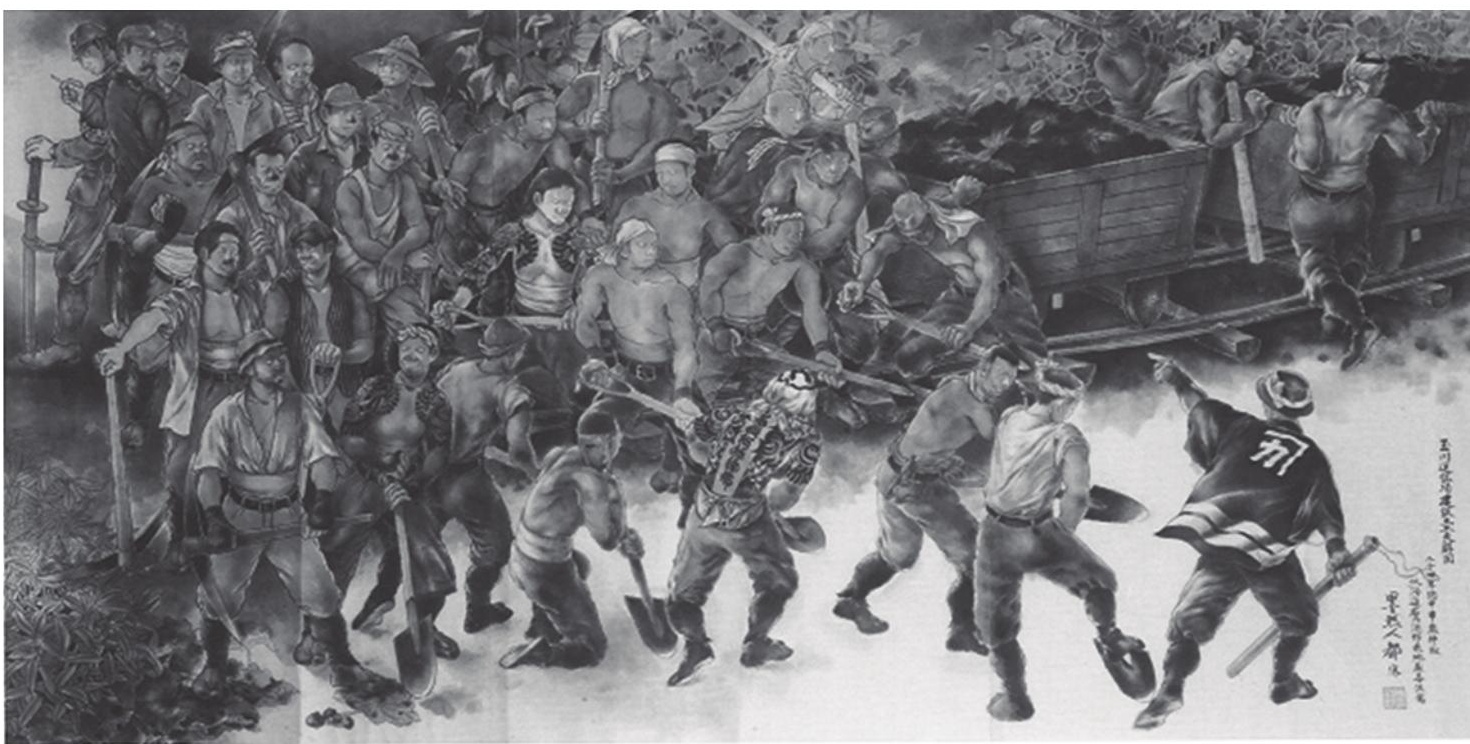

Figure 2. Chinese POWs Arriving at Mine

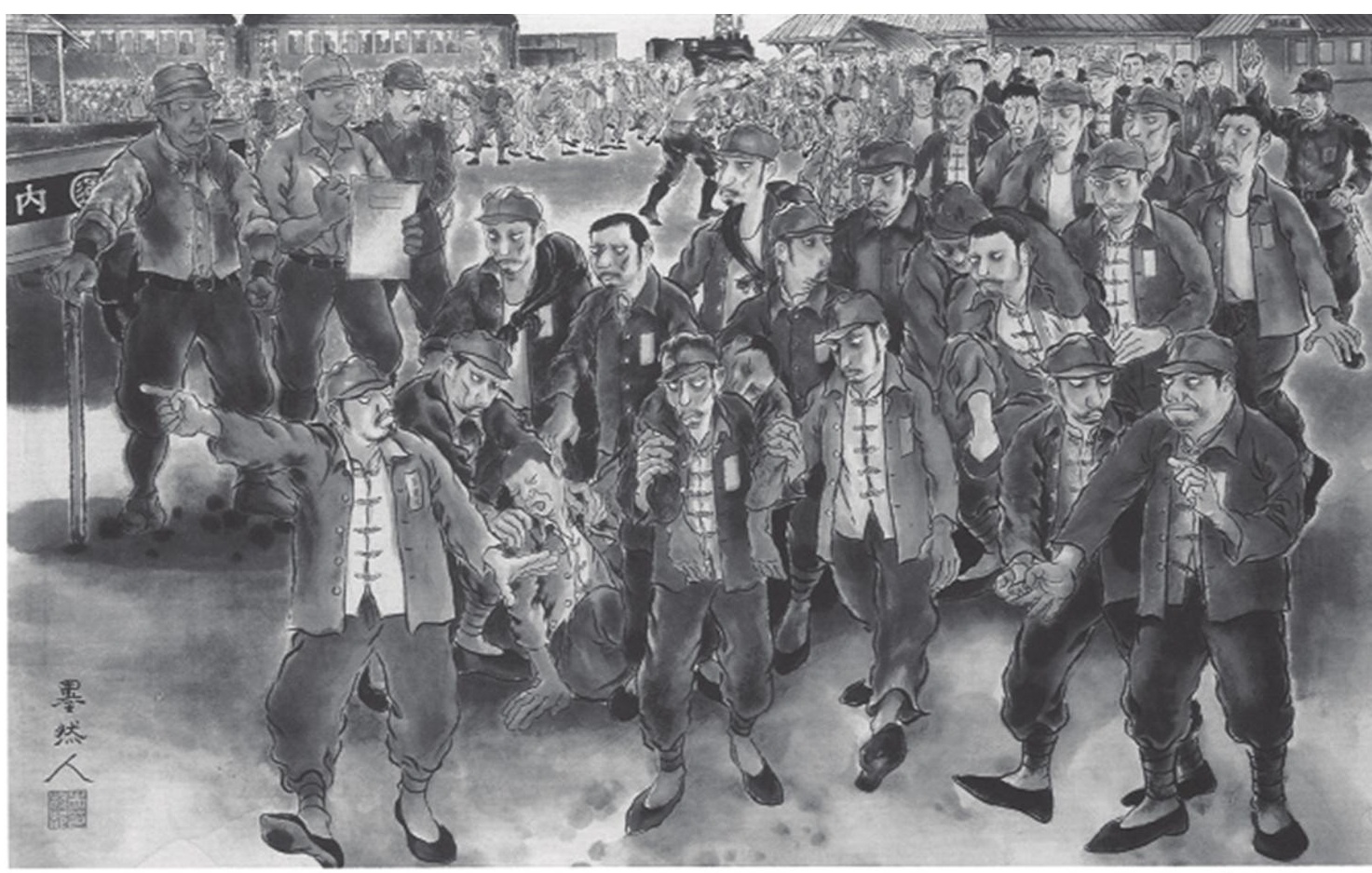


Figure 3. Bringing Food to Dying

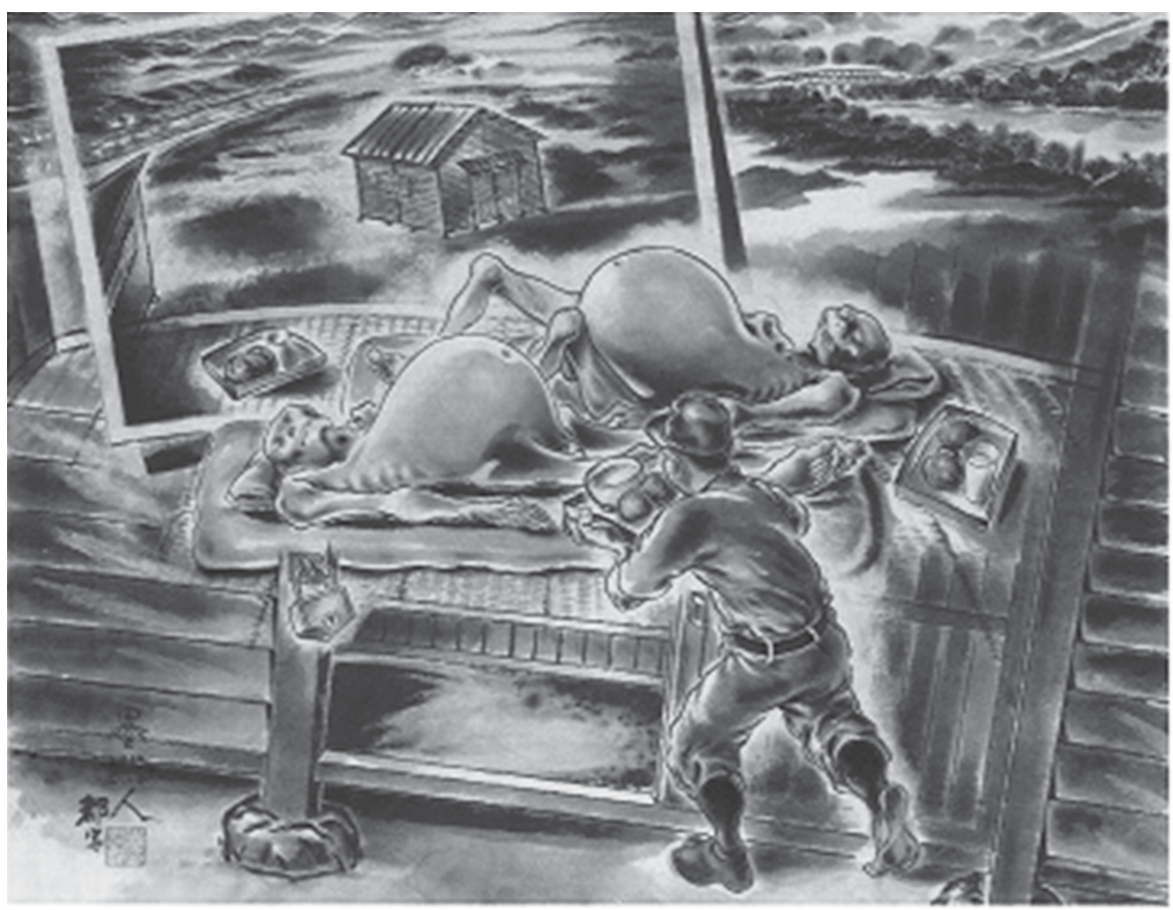

Figure 4. Surrender Responses

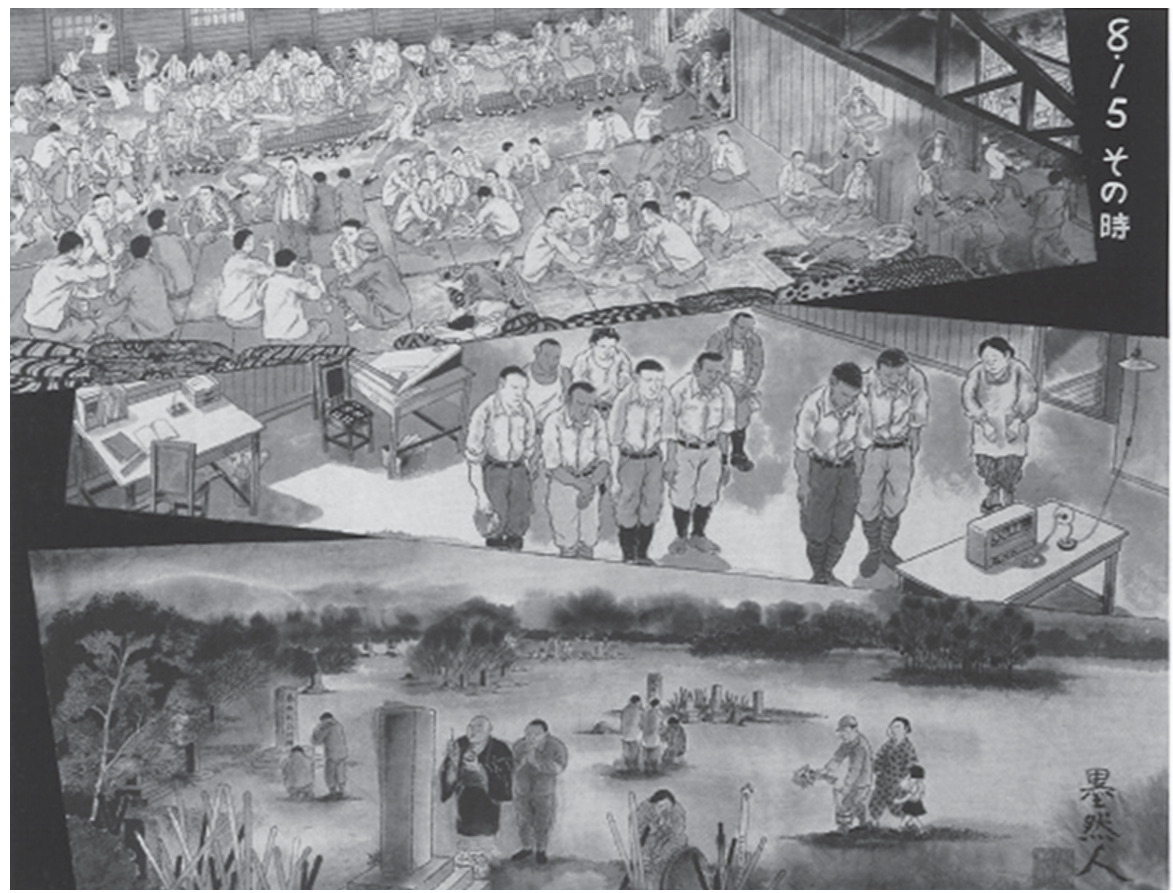


Figure 5. Station Departure

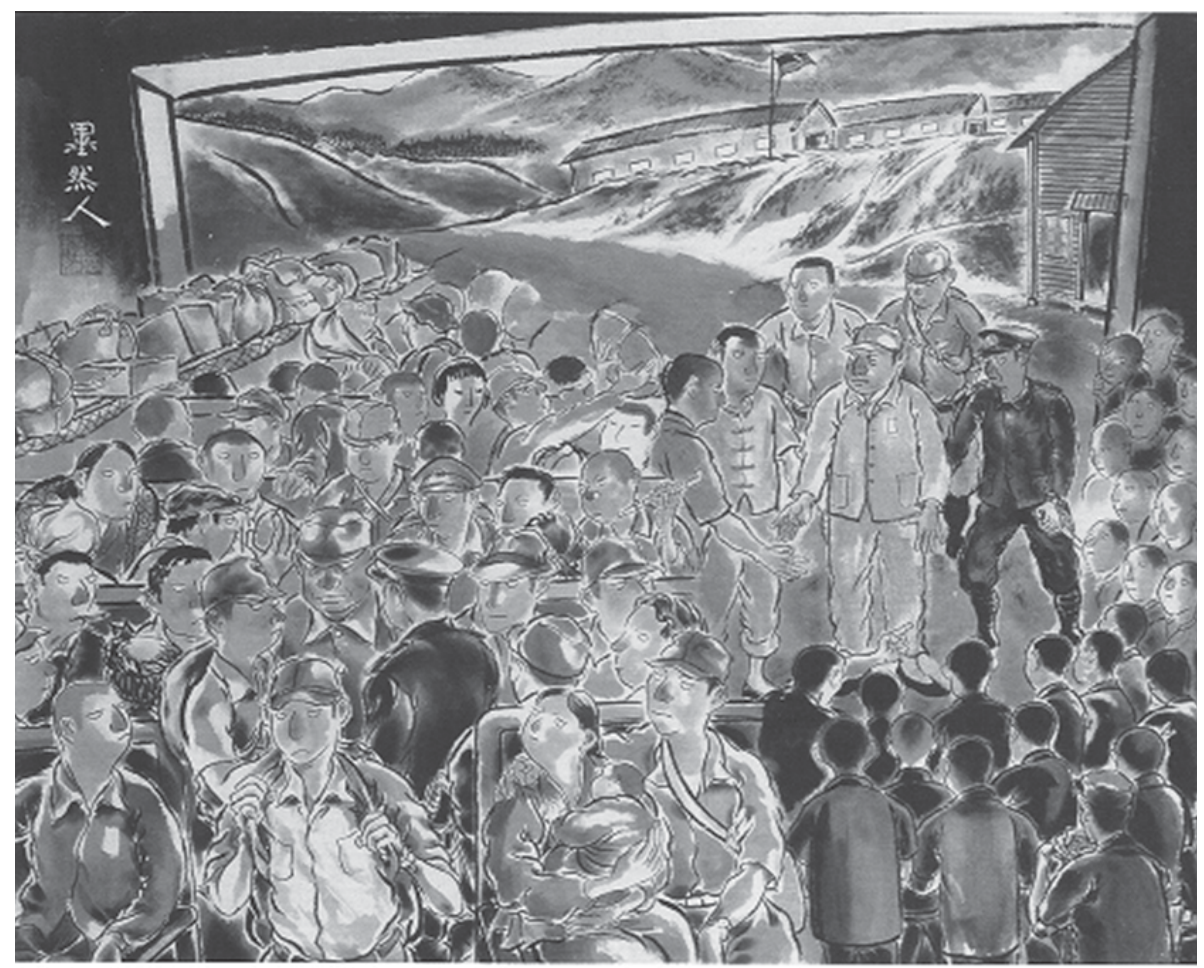

Figure 6. Hanaoka Incident

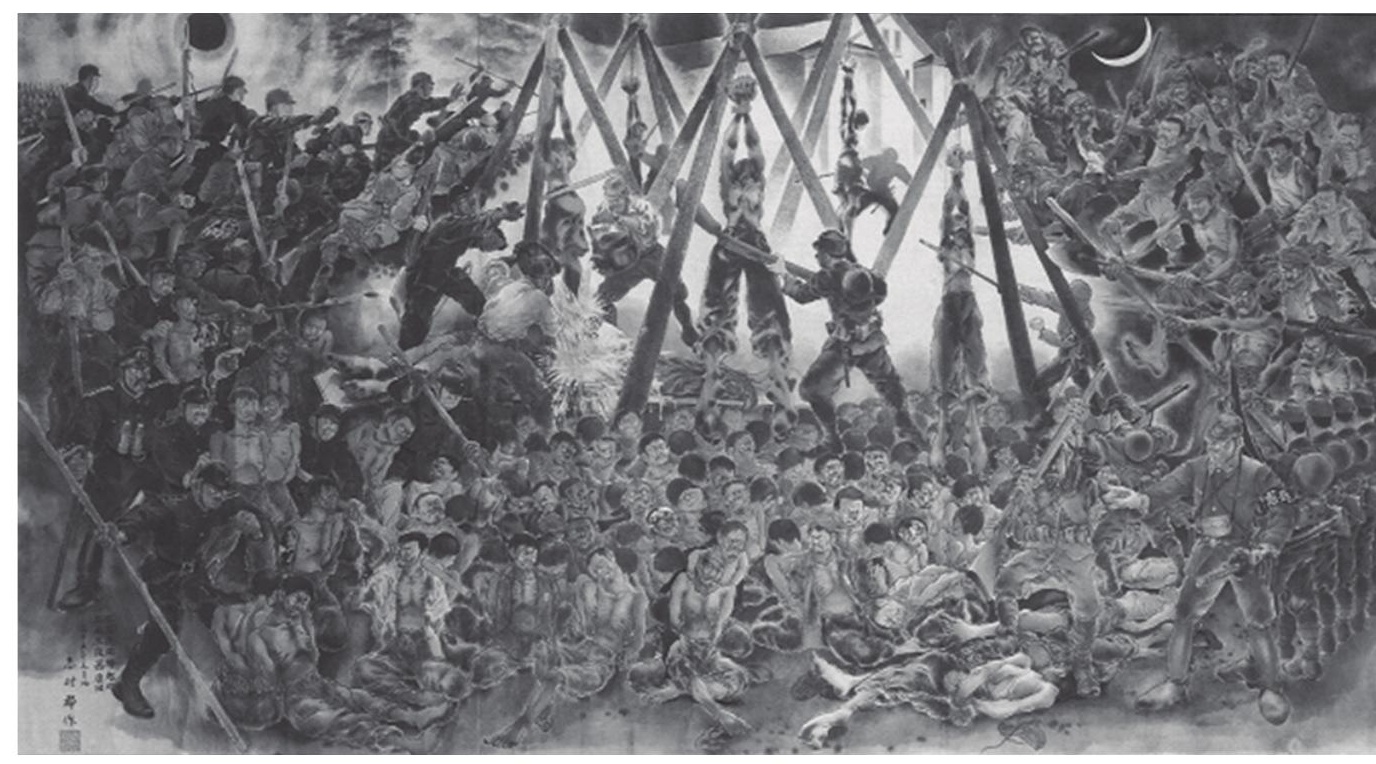


II, but Japan's militarization was a constant in the decades prior to the Pacific War. The convict laborers are all depicted as muscular, tough, and fierce. One can see defiance in their faces even as they work.

This muscular appearance and fierceness are absent when he portrays the Chinese POWs arriving in 1945 to replace the previous workers. Hundreds of them are being escorted from rail cars, overseen by Kempeitai and company supervisors, one of whom is keeping track of numbers with a pencil and paper. The Chinese are exhausted, suffering from hunger, and some appear sick, a condition resulting from the horrendous journey by ship from China to Japan.

Other scenes, always with a Kempeitai officer observing the workers suspiciously, include kitchen operations, a dorm scene with hundreds of men packed into one-mat tatami spaces, health checks of men whose ribs are visible from starvation, and teams carrying the coal baskets. In June 1945, a huge mine collapse sent tons of soft earth from the open pit onto the Chinese laborers. Bokunenjin portrays the rescue effort, but also the anger of the miners over the appalling conditions that caused deaths and injuries. When American planes bomb some of the site, we view the scene from a hillside where the Chinese have retreated, with one Chinese POW raising his fist in defiance as if welcoming this destruction of part of the slave camp.

The Chinese resisted their Japanese captors in a number of ways. Bokunenjin witnessed an escape through a dirt latrine hole in the toilet facilities. Many were later caught, and their beatings by the Kempeitai and supervisors, including violent torture, are depicted in the drawings that follow. In an execution scene of a ringleader, a Kempeitai officer, an Imperial Army soldier, and a Kajima-gumi supervisor sit at a table looking away, scowling in anger. A few escapees were never found, and Bokunenjin thinks that they may have eventually made it back to China, as the war's end was only a month away.

Some Chinese developed fatal illnesses and were put in a wooden house that was locked, where they were left to die alone. Bokunenjin portrays himself secretly bringing food to the dying men, their naked bodies bloated enormously as they lie helpless on mats. This was his way of offering them respect, even if they had no hope of living or even consuming the food he brought them. In a similar scene, he drew the cremation of a Chinese man, his comrades sitting around the funeral pyre in grief, while Bokunenjin looks on with them, standing and tending the funeral coals. An empty sake bottle filled with flowers in memory of the deceased man sits behind the group in the lower left corner.

August 15, the day of Japan's surrender, is depicted in a painting divided into three horizontal scenes. In the middle scene, Japanese stand silently in front of a radio listening to the Emperor's speech, their heads bowed solemnly in sadness. In the scene above, hundreds of Chinese sit in groups in the dormitory, talking and preparing to leave the camp, oblivious to the solemn surrender ceremony. The lower scene shows Japanese soldiers and their families in a cemetery scattered 
in small clusters praying for family members who died during the war. A final painting in Bokunenjin's Hokkaido Kajima-gumi forced labor series depicts the late-August departure of Japanese mine personnel and Kempeitai for home at the train station. U.S. occupation forces now control the area. In the foreground, hundreds of Japanese and Chinese wait at the platform, while behind the group an American flag flies from a pole in front of the company buildings. An officer who was in charge of the Chinese forced laborers and who committed many abuses against them is being bid farewell by his underlings, a Kempeitai officer with sword standing beside him. In the lower right corner Bokunenjin stands among the Chinese hidden from the view of these officers, and is secretly drawing the labor boss's portrait.

Bokunenjin kept this portrait and later presented it as evidence when this officer was tried for war crimes by authorities in the 77th Division of the U.S. Army, which then occupied Hokkaido. His testimony at the Sapporo trial, in January 1946, helped convict this officer; but as Bokunenjin relates, "luckily" he himself was released, even though he too could have been held responsible for the Kajima-gumi Mine forced labor atrocities.

The most shocking of Bokunenjin's drawings is a huge depiction of the Akita Prefecture revolt by Chinese forced laborers at Kajima-gumi's Hanaoka Mine in Odate. The Chinese killed five Japanese mining supervisors and then escaped to the surrounding hills, but were brutally hunted down by Kempeitai, company supervisors, Imperial Army soldiers, and even local Japanese villagers. These four types are symbolically portrayed in a scene where soldiers have strung up the leaders by ropes and are beating them, while other Chinese are sitting in misery, some already dead, waiting for their fate to be delivered by this violent mob. Of the 986 Chinese brought to the mine between August 1944 and June 1945, a total of 418 died by the end of 1945 from their treatment, including executions and torture at the time of the uprising. In 1995, survivors and relatives of the deceased started litigation against Kajima Corporation for damages; they won their case in 2000 at the Tokyo High Court. As settlement, Kajima agreed to establish a compensation fund of 500 million yen. This was the first case involving Chinese forced laborers to succeed in a Japanese court (Kyodo News International 2000; Underwood 2010). The court case made the "Hanaoka Incident" famous in Japan. However, Kajima-gumi's brutality at the Empire Coal Mining Development project in Hokkaido remained a story hidden from view until Bokunenjin's personal investigation, captured later in his sumi drawings.

Bokunenjin attempted to restore the historical record that postwar Japanese in power have sought to eradicate. His anger at these crimes of his own countrymen is evident in every painting, but he never holds himself blameless.

When envisioning this remote scene, I feel a sense of shame together with a sense of introspection. Even now I remember indignantly my feeling opposed to the business 
of forced labor. For that reason, my own memory is distinct. For whoever's sake this [work of art] is, or whoever might question the reliability of this memory, within this country my intention is to make it my own responsibility. It is a belated self-criticism that is embodied in these unskilled drawings, which substantiate that forced labor violence was committed by those operating forced labor enterprises. This is my desire with these drawings. In my capacity of being a teacher preparing his affairs before his death, there is in them both the legacy of suffering and what the cause of this suffering was. Until I die, I will continue to paint even if it is as an elderly person who seeks redemption sixty years later, and who seeks to complete these as a matter of selfcriticism. Even with these, the war for me will not have an end (Shimura 2008a).

In this duality of Bokunenjin's outlook, expressed in his drawings and conveyed in his words, there is both a criticism of Japan's wartime crimes against Chinese POWs who were used as forced laborers, but also an acceptance of his own responsibility expressed humbly and as self-criticism. He never views himself as a victim, but he recognizes others as victims even as he exposes those who were in charge (Shimura 2008a; 2008b).

\section{Fukagawa’s Poetry on Hiroshima’s Korean Forced Laborers}

Bokunenjin's artistry has parallels with the tanka poetry of Fukagawa Munetoshi (深川宗俊), who uncovered the hidden history of Korean forced labor at Mitsubishi's Hiroshima shipyard. The Koreans who survived the atomic bomb became hibakusha like Fukagawa, who was Japanese. Those who knew Fukagawa have said that he preferred to be remembered as a tanka poet. He was also a peace activist, a journalist, and later in life had his own printing shop, but it was his identity as a poet that he seemed to value most. His grave has two doves sitting on a stone, with a poem to his mother engraved on it, affirming this sense of identity.

Fukagawa, like Bokunenjin, was a dormitory supervisor of forced laborers in 1945. Like Bokunenjin, he befriended these captive workers and sympathized with their plight. Like Bokunenjin, he could do little against the war machine that compelled him to act within it. And Fukagawa worked within a private company-a powerful zaibatsu - that was protected by the Kempeitai, the Japanese military, and a government run as a dictatorship.

After the atomic bomb destroyed Hiroshima, doing only minimal damage to the Mitsubishi Shipyard due to its distance from the hypocenter, the Korean forced laborers gained their freedom and by September departed for their homeland. The group Fukagawa had come to know well reached Shimonoseki at the northern tip of Kyushu. From that locale they paid a fishing vessel to take them across the Korea Strait to Busan. The boat was overloaded, however, and got caught in the terrible typhoon that ravaged Japan that month. They perished at sea, and their bodies washed ashore on Iki Island. None of this history was known 
to Fukagawa until the day he read a news story from South Korea about a Korean he had known at Mitsubishi who was searching for his missing brother. This man, No Chyangsoo, had discovered information suggesting that remains of Koreans who were returning from Japan after the war might be on Iki Island. Fukagawa contacted No, and his first journey to South Korea began with a reunion after 28 years, followed by many more journeys over the ensuing years. Eventually, he and No assisted in repatriating the remains of the Korean laborers from Iki Island to their families in South Korea. As Fukagawa did his own research on the Mitsubishi role in this affair, he encountered a disturbing cover-up. He learned that Mitsubishi had not sent half of the wages of each Korean to their families back in Korea, as promised. However, he got no cooperation from the company (Fukagawa 1992; Palmer 2006).

In his journeys to South Korea, Fukagawa became friends with a major Korean poet. Fukagawa's tanka draws on all these experiences. Even though his poetry is infused with his social and political perspective on events, his verse is not polemical. He used his investigations and travels on behalf of the Korean forced laborers as source material for his writings and poetry. His creative work reflects the reality of the lives of hibakusha, whether Korean or Japanese. His poems constantly cross the barriers of countries and nationalities rather than focusing solely on Hiroshima and the atomic bombing.

Fukagawa wrote in a postwar era when there were many "atomic bomb poets" in Hiroshima, and he became part of one of these poet circles. At the time, Hiroshima's most famous atomic bomb poet was Toge Sankichi, who became a vocal leftwing activist and Communist Party member (Minear 1990). The year 1950 marked a major change in Hiroshima's peace movement because of the beginning of the Korean War. The United States, through its occupation authority, essentially governed Japan and by that time could use Japan as a rear logistical base for this new war. Hiroshima's nascent movement against nuclear weapons, politically confined by the occupation's censorship, gained new momentum as a broader antiwar movement. Hiroshima's trade union movement also exploded with strikes and actions in response to growing anti-left and antiunion repression. Fukagawa continued working at the Mitsubishi shipyard after World War II, but was fired for his involvement in the shipyard strike. Toge and other poets, like Fukagawa, responded politically and culturally to this new antiwar and pro-labor upsurge through their poetry. Toge's circle belonged to Shin Nihon Bungakukai (New Japan Literature Association), while Fukagawa's circle was part of the Jinmin Bungaku (People's Literature) movement. Looking back, Fukagawa related how this decisive year-the fifth anniversary of the atomic bombing of Hiroshima and the commencement of the Korean War-brought the two literary movements together "despite their differences because of the year's difficult season" that all in Hiroshima remembered. In his small literary magazine, Fukagawa wrote a sympathetic explanation of Toge's masterpiece "The 
Atomic Bomb Poems." He and Toge, Fukagawa later recalled, "in fact were both hibakusha" (Fukagawa 1970, 51).

These poetry circles differed from the more popular atomic bomb poetry linked to testimonies of survivors, the most famous of these poets was Sadako Kurihara (Nagatsu et al. 2007). Fukagawa and Toge were friends, despite their contrasting approaches to poetry, and they shared a common creative environment in Hiroshima's prolific postwar literary world. Unlike Toge, however, Fukagawa's antiwar poetry went beyond Hiroshima's atomic bomb and the city's Japanese. In contrast to Toge, who did not have a job in Hiroshima's war industry, Fukagawa's work at the Mitsubishi Hiroshima Shipyard directly supervising Korean forced laborers brought him face to face with fascist Japan's militaryindustrial complex. No other "atomic bomb poet" confronted Japan's wartime economy and its forced labor system so directly. In 2008, the Hiroshima Public Library held a special exhibit highlighting the most famous of Hiroshima's poets, with biographies and selections from their work. Toge was featured, along with other Hiroshima poets, some connected to the postwar antiwar literary trends, and others earlier or later whose works did not focus on antiwar sentiment.

Fukagawa had no presence in this exhibit, and any mention of Korean forced labor was absent in the exhibit's contextual history. But in some ways his work has had an alternative influence that this type of exhibit did not recognize. It was Fukagawa who helped ignite the movement for justice for Korean hibakusha, not just as hibakusha, but also as kyosei renko. Certainly Toge's poetry of 1950 was the initial poetic defining point for the Japanese hibakusha experience of Hiroshima. However, Fukagawa's poetry can be viewed as a poetic defining point for Japanese/Korean reconciliation because of the way he linked the suffering caused by the atomic bomb with the suffering caused by Japan's forced labor regime toward Koreans.

Fukagawa's poem "Kyosei Renko" ("Forced Labor") speaks directly to the Korean hibakusha as the double victims of atomic bomb-related disease (from the Americans) and forced labor (from the Japanese). In this poem he modifies the five-verse traditional syllable count (5-7-5-7-7) of tanka freely, while retaining the overall spirit of traditional tanka.

Passing over Mount Kaya / I could hear the voices / of Hiroshima /

In the snow blizzard / As I approached Seoul

I crossed the Han River / Many times until / At Su-on Village /

I found the hibakusha / Gathering

Hiroshima hibakusha / Continue to die one by one - / Now in Korea /

Their identity - these dead - / Finally known for certain

At the town's train station / Where forced labor began / I heard the sound /

Of the bereaved families' jeogori / Waving in the early winter wind

Leave my corpse / In front of the Japanese Embassy - / So said I Nam Su / 
His last request before dying / In desperate poverty Struggling with / Atomic bomb paralysis / I Nam Su /

Took his last breath as he died / In the season when azaleas bloom While speaking / Over and over in halting / Japanese words /

Hibakusha I Sun Oku / Wiped the tears from her eyes In Boku Sun cried / Wanting to go to Hiroshima / He was not aware/

It had already spread / To his lungs

We will not see / Each other anymore / Words of farewell /

Exchanged in Korean / In the underground market The sunset's afterglow / Has already died out / Crossing Han River /

The deep blue water flows / As if in a mass of darkness The Hiroshima hibakusha / Of Habu Chyon ${ }^{3}$ Village / Are many - /

They truly know what it means / To live on the margins of life (Fukagawa 1990) ${ }^{4}$

In his journeys to South Korea, Fukagawa was accompanied by a younger man, Hirano Nobuto, who was a high school teacher in Nagasaki, but who used every moment of his free time to assist in the movement on behalf of the Koreans. Hirano has visited South Korea hundreds of times, continuing to make these journeys in his ongoing research on overseas hibakusha who have not received full recognition from the Japanese government. Similar to Fukagawa's efforts, Hirano's research and publications have assisted attorneys engaged in hibakusha compensation litigation directed at the Japanese government, while also providing extensive evidence of Mitsubishis role in using Korean forced laborers. The research has involved locating documents, interviewing surviving forced laborers, and compiling data from these sources. Before every court session, Hirano and the Overseas Hibakusha Support Network of Nagasaki have held protest rallies, including speeches by hibakusha (Hirano 2012).

The Zainichi Korean-Japanese community in Japan has done extensive research on the history of Korean forced labor under Imperial Japan. ${ }^{5}$ What makes the Overseas Hibakusha Support Network different is that people of Japanese ethnic background have played a crucial leadership role in creating a single movement that has brought together the issues of opposition to nuclear weapons, hibakusha recognition, and recognition of the history of forced labor. Korean hibakusha, who were denied compensation by the Japanese government because they returned to Korea after the war, have been able to prove that they were in Hiroshima at the time of the atomic bombs by providing evidence that they were forced to work for Mitsubishi's Hiroshima Shipbuilding Complex in the period before the bombing. The trial evidence is not just in their testimony, but also in the very documents of the company. The origin of the movement, from the Japanese activist side, sprang largely from Fukagawa's personal investigations. The spiritual source of the movement came from his cultural experiences with the 
Koreans he came to know in 1945, and later during his journeys to Korea.

\section{Postwar Generation Activists for Overseas Hibakusha Support}

In recent years, Hirano and the Overseas Hibakusha Support Network have gone beyond just working on behalf of Koreans. Their support work and advocacy has encompassed former Allied Powers' POWs who were in Nagasaki at the time of the atomic bombing, other Asians who were exposed to the bombs such as Taiwanese, and also those impacted by later atomic bomb testing in many parts of the world (Hirano 2010; Hirano 2012). Hirano has been involved in conventional social movement protests, as well as research and publications to publicize injustices, litigation in pursuit of justice, and organizations created to support these activities.

However, others in the movements linked to Korean hibakusha issues have become involved through alternative routes, and they have engaged in types of activism that are not strictly organizational or protest oriented. Their activism came from variants of the experience-based cultural model that Bokunenjin and Fukagawa pioneered through their art and poetry. Among these are Kimura Hideto, a retired high school teacher from Nagasaki, and Yoshioka Itsuko, who is a daycare worker in Hiroshima.

Kimura taught English before he retired, and so has had a proclivity to learning foreign languages. In previous years he traveled to the United States and England to brush up his English, but when he was 45 he decided to study the Korean language as a result of an earlier trip to South Korea. By the time he retired at age 62 he could speak and read Korean. He particularly enjoyed reading historical novels in Korean that were set in the late 19th century through the period of Japanese colonialism and the Pacific War. His favorite Korean novels were about the anti-Japanese partisans based in the Jirisan mountains in the western part of the country. Through these novels he learned much about the history of Japan's control over Korea and the resistance to Japanese colonialism. From the style of writing in these novels he acquired knowledge of the dialect of this remote region that differed from the standard urban Korean of Seoul.

Many teachers and peace activists from Hiroshima and Nagasaki have volunteered as English interpreters at the peace museums, including Kimura. Although the volunteers are people who have bilingual experience, they take a highly professional approach to their work, with a focus on precise and accurate information based on the Hiroshima Handbook (Japanese-English) (Ogura 1995). Kimura was invited to a social gathering of interpreters and met someone who told him about Stonewalk. This peace movement for reconciliation began in the United States, initially in Boston. The peace activists wanted a public apology by the United States for using the atomic bombs on Japan, and they organized a 
walk from Hiroshima to Nagasaki that people from other countries, including Japanese, joined (Stonewalk Website 2012). Kimura's friend at the interpreters' gathering had the idea of organizing a similar "Stonewalk" calling for a public apology by Japan for the colonization of Korea and the many abuses that resulted from Japanese control. The walk was planned along the western part of South Korea, including the Jirisan mountain region. Kimura supported the objective of the Korean Stonewalk, but his decision to join was initially because he could visit the locations in his favorite Korean historical novels. When he was on the walk, the organizers were able to use his familiarity with the local Korean dialect when Japanese wanted to communicate with villagers along the way. One town they walked through was Hapcheon, the subject of Fukagawa's poem, where it is estimated that a very large number of Korean forced laborers were obtained by Kempeitai and Mitsubishi representatives from that town and surrounding villages. Some believe that this area had the highest percentage of Korean hibakusha (Fukagawa 1992; Kimura 2012).

Kimura has continued to assist Hirano and others involved in Korean hibakusha litigation for medical benefits and compensation payments, playing a crucial role in bridging the language divide between Japanese and Koreans. He has regularly volunteered as an interpreter, too, at a local Nagasaki hospital where there are Korean patients. Both Hiroshima and Nagasaki have a substantial Korean population, with communities that go back several decades prior to the forced labor era of the late 1930s through 1945. This cultural connection of language and people contributed to Kimura's motivation to become involved with these social justice and peace movements (Kimura 2012). Direct person-toperson contact is not new to social movements. Increasingly, however, this direct personal contact is having a significant role in shaping peace and reconciliation movements in East Asia in a new way. It has been transformed into an extension of the global social networking phenomenon of the last decade's internet-driven alternative politics (Castells 2012).

The example of Yoshioka Itsuko is representative of the many women who volunteer as English interpreters for the Hiroshima Peace Memorial Museum. However, she has expanded her involvement in the anti-nuclear peace movement beyond the Museum, and in recent years has assisted the movement on behalf of Korean hibakusha. She has used her English skills to assist those coming from countries such as Australia and the United States who are active in the antinuclear peace movement.

Her interest in Japan-Korea reconciliation goes back to her high school days in Fukuyama City. She was involved in a student social science research club and she worked on a project focused on Korea under Japanese rule and during the Korean War. At that time she began corresponding with a pen pal in Korea, which made her aware of how little she knew about Korea's historical relationship with Japan. In the last decade she went to South Korea to attend a conference 
against nuclear weapons and was able to stay at the home of a Korean who also was attending the conference. She then began to sponsor homestay visits for Koreans at her own house in Hiroshima.

The official Hiroshima and Nagasaki memorials of atomic bomb victims in the past focused solely on Japanese. This narrowness was reflected within some of the peace organizations. But people like Yoshioka sought to bring out the role of Japanese aggression in Korea along with the issue of the Korean hibakusha. She became involved in a Japanese peace organization that wanted to have an exhibition in Seoul on the Hiroshima atomic bombing. She suggested that this display should also include the history of Imperial Japan's aggression toward Korea. As a result, they held the exhibit based on both histories. This dual approach to the exhibit, and to both sides of World War II history, helped educate her Japanese colleagues who were less familiar with Korea's historical experience (Yoshioka 2012).

This role of consciousness, based both on an awareness of the real history of Korea and Japan and on direct personal experience, is certainly the starting point for an effective movement for reconciliation between Koreans and Japanese. It is a social process that can apply equally to reconciliation between Chinese and Japanese. The initiative for this reconciliation, to be truly genuine and effective, has to come from people whose country was the original aggressor, not just from those who were victimized by Imperial Japan.

\section{Conclusion}

What are the future prospects for a broader movement for reconciliation between Japan and its neighbors, China and Korea (South and North) around World War II issues? Is there an alternative to the older social movement model of traditional organizations, with committees, meetings, and directing leaders, or the mobilization model focused on large demonstrations that come and go-whether focused on war (the invasion of Iraq) or environmental crises (the Fukushima nuclear catastrophe)? The alternative experiential-cultural approach presented here allows for personal involvement that is more sustainable over the long term, and perhaps deeper in the way it brings people together across cultures and nations.

However, three particular problems need to be addressed in order to further this approach. First, the youngest adult generation must not only be involved, but must also assume leadership in the future. Bokunenjin and Fukagawa both came from the World War II generation of Japanese. Those who came after them are identified with the 1960s and 1970s antiwar and rights movement generation of social activism. In the decades since then, social movements have receded in size and have also become more fragmented due to the range of social and 
political issues that have appeared. The U.S.-led invasion of Afghanistan and later invasion of Iraq, following the September 11, 2001 terrorist attacks reignited antiwar protests, but these could not be sustained. The old models-constant demonstrations and traditional organization-failed to be enough to continue a broad, popular peace movement. The rise of the Internet, new forms of social networking and mobilizing (e.g., Occupy Wall Street), and a new awareness of how reconciliation over historical injustices can be linked to peace movement initiatives have opened alternative possibilities. These do not necessarily exclude mobilizing for demonstrations or forming stable organizations, but they have the possibility of transforming older models into something different, beyond their limitations. It is the young generation that needs to lead in developing these new possibilities.

Second, new media in the arts must play a role, but traditional forms of the arts can be integrated into this. The sumi drawings of Bokunenjin and the tanka of Fukagawa come from some of the oldest Japanese-and East Asianartistic forms, yet they can be distributed beyond local places via the Internet and electronic publishing. Film, online video, street art, new types of writing and poetry, and varieties of new music all need to be at the core of any new experiential-cultural social movement, but these should also embrace traditional arts in order to be most effective. The continued involvement of young people in live music, live poetry sessions, popular and street art, and the fact that they value face-to-face interaction more than ever testifies to the possibilities of this interactive character of the contemporary and the traditional.

Third, new types of organization are required, beyond just committees and meetings. Here is where decentralized social networking can advance a movement for reconciliation. Such movements often involve dealing with huge amounts of information, but this can be more easily conveyed and discussed electronically than through committee meetings and standard reports to committees for select individuals. This alternative model also allows faster action-and interactionacross distances, even as people separated by distance work out effective ways to gather on a person-to-person basis that may involve two people, a number of people, or even hundreds and thousands, depending on the nature of the activity. This new form of organization also breaks down nationalist barriers and allows for far better global interaction, but it requires new facility with languages, which many in the current reconciliation movement are pursuing. The examples of the Japanese activists of Hiroshima and Nagasaki are a window into these future possibilities.

\section{Notes}

1. This section is based on Shimura interview (2008) and Shimura catalog (2008). 
Catalog text translation is by David Palmer.

2. Figure 1 to Figure 6 permitted by Bokunenjin Shimura on April 20, 2013.

3. Habu Chyon is the Japanese pronunciation. Hapcheon is the Korean pronunciation.

4. Translation by David Palmer. Tets Kimura and Shoko Yoneyama offered valuable suggestions on this translation.

5. For some of these publications (in Japanese) see references in Palmer (2006; 2008).

\section{References}

Berlin, Ira. 2010. The Making of African America: The Four Great Migrations. New York: Penguin.

Blackman, Douglas A. 2008. Slavery by Another Name: The Re-enslavement of Black Americans from the Civil War to World War II. New York: Random House.

Buruma, Ian. 1994. Wages of Guilt: Memories of War in Germany and Japan. London: Jonathan Cape.

Castells, Manuel. 2012. Networks of Outrage and Hope: Social Movements in the Internet Age. Cambridge, UK: Polity.

Dower, John. 2012. Ways of Forgetting, Ways of Remembering: Japan in the Modern World. New York: New Press.

Dower, John, and John Junkerman, eds. 1986. The Hiroshima Murals: The Art of Iri Maruki and Toshi Maruki. Tokyo: Kodansha International.

Fukagawa Munetoshi. 1970. 1950 nen 8 gatsu 6 nichi: Chosen senso ka no Hiroshima. Hiroshima: Gensuibakukinshi Hiroshimashi Sangikai.

Fukagawa Munetoshi. 1990. Rento. Tokyo: Tanka shimbunsha.

Fukagawa Munetoshi. [1974] 1992. Umi ni kieta ni hibaku Chosenjin choyoko: Chinkon no kaikyo. Tokyo: Akashi Shoten.

Fukagawa, Munetoshi. 2004. Interview with David Palmer, and interpreters Ozaki Mieko and Aihara Yumi, Hiroshima. September 27.

Fukuoka, Yasunori, and Yukiko Tsujiyama. 2010. "Young Koreans against Ethnic Discrimination in Japan: A Case Study of a Grassroots and Networking-style Movement." In East Asian Social Movements: Power, Protest, and Change in a Dynamic Region, eds. Jeffrey Broadbent and Vicky Brockman. New York: Springer, 113-40.

Funabashi, Harutoshi. 2010. "The Duality of Social Systems and the Environmental Movement in Japan.” In East Asian Social Movements: Power, Protest, and Change in a Dynamic Region, eds. Jeffrey Broadbent and Vicky Brockman. New York: Springer, 37-62.

Hirano Nobuto. 2010. Umi no muko no hibakushatachi: Zaigai hibakusha mondai no no tameni. Tokyo: Kabushiki kaisha hachigatsukan.

Hirano, Nobuto. 2012. Interview with David Palmer, and interpreter Kimura Hideto, Nagasaki. October 4.

Hogan, Michael, ed. 1996. Hiroshima in History and Memory. Cambridge, UK: Cambridge University Press.

Kim, Mikyoung, and Barry Schwartz, eds. 2010. Northeast Asia's Difficult Past: Essays in Collective Memory. London and New York: Palgrave Publishers.

Kimura, Hideto. 2012. Interview with David Palmer, Nagasaki. October 4. 
Kurita, Nobuyoshi. 2010. “The Long-term Effects of Political Socialization during Late1960s Student Protest." In East Asian Social Movements: Power, Protest, and Change in a Dynamic Region, eds. Jeffrey Broadbent and Vicky Brockman. New York: Springer, 99-112.

Kyodo News International. 2000. "Kajima to Compensate Chinese over WWII Forced Labor." November 29. http://www.thefreelibrary.com/Kajima+to+compensate+ Chinese+over+WWII+forced+labor\%2B.-a068162617 (accessed March 28, 2013).

Minear, Richard, ed. and trans. 1990. Hiroshima: Three Witnesses. Princeton: Princeton University Press.

Nagatsu, Kozaburo, Hisao Suzuki, and Yamamoto Toshio, eds. 2007. Against Nuclear Weapons: A Collection of Poems by 181 Poets, 1945-2007. Koriyama Naoshi, Mizusaki Noriko, Oyama Masumi, and Aya Yuhki, trans. Tokyo: Coal Sack Publishing.

Oe, Kenzaburo. 1981. Hiroshima Notes. New York: Grove Press.

Ogura Keiko, ed. 1995. Hiroshima Handbook (Japanese-English). Hiroshima: The Hiroshima Interpreters for Peace (HIP).

Orr, James J. 2001. The Victim as Hero: Ideologies of Peace and National Identity in Postwar Japan. Honolulu: University of Hawai'i Press.

Palmer, David. 2006. “The Straits of Dead Souls: One Man's Investigation into the Disappearance of Mitsubishi Hiroshima's Korean Forced Labourers." Japanese Studies 26 (3): 335-51.

Palmer, David. 2008. "Korean Hibakusha, Japan's Supreme Court and the International Community: Can the U.S. and Japan Confront Forced Labor and Atomic Bombing?" Japan Focus, February 20. http://www.japanfocus.org/-David-Palmer/2670 (accessed March 21, 2013).

Sasaki-Uemura, Wesley. 2001. Organizing the Spontaneous: Citizen Protest in Postwar Japan. Honolulu: University of Hawai'i Press.

Shimura Bokunenjin. 2008a. Sumigaki: Chugokujin kyoseirenko no zu. Kyoto: Chyugokujin kyoseirenko rengikai rengo o tsukaeru kai, Ryukoku University.

Shimura, Bokunenjin. 2008b. Interview with David Palmer, and interpreter Yoshioka Itsuko, Kobe. September 25.

Stonewalk Website. 2012. "A Global Pilgrimage Honoring Civilian Casualties of War." http://www.stonewalk.org/stonewalk/history.htm (accessed March 21, 2013).

Underwood, William. 2006. "The Japanese Court, Mitsubishi and Corporate Resistance to Chinese Forced Labor Redress." The Asia-Pacific Journal: Japan Focus, March 29. http://www.japanfocus.org/-William-Underwood/1636 (accessed April 12, 2013).

Underwood, William. 2010. "Redress Crossroads in Japan: Decisive Phase in Campaigns to Compensate Korean and Chinese Wartime Forced Laborers." The Asia-Pacific Journal, 30-1-10. July 26. http://www.japanfocus.org/-William-Underwood/3387 (accessed April 12, 2013).

Wittner, Lawrence. 1993. The Struggle Against the Bomb, Volume One: One World or None: A History of the World Nuclear Disarmament Movement through 1953. Stanford: Stanford University Press.

Wittner, Lawrence. 1997. The Struggle Against the Bomb, Volume Two: Resisting the Bomb: A History of the World Nuclear Disarmament Movement, 1954-1970. Stanford: Stanford University Press.

Yoneyama, Lisa. 1999. Hiroshima Traces: Time, Space, and the Dialectics of Memory. 
Berkeley: University of California Press.

Yoshioka, Itsuko. 2012. Interview with David Palmer, Hiroshima. October 1.

David Palmer is Senior Lecturer in the School of International Studies, Flinders University, Adelaide, Australia. He received a Ph.D. in History from Brandeis University. His publications include Organizing the Shipyards: Union Strategy in Three Northeast Ports, 1933-45 (1998) and "The Straits of Dead Souls: One Man's Investigation into the Disappearance of Mitsubishi Hiroshima's Korean Forced Labourers," Japanese Studies (December 2006). Among his current projects is one on the history of Nagasaki's workers. He was a conscientious objector during the Vietnam War and has continued to contribute to the peace movements in Australia and Japan. 